AL IBTIDA: JURNAL PENDIDIKAN GURU MI (2019) Vol 6 (1): 63-76

DOI: http://dx.doi.org/ 10.24235/al.ibtida.snj.v6i1.3821

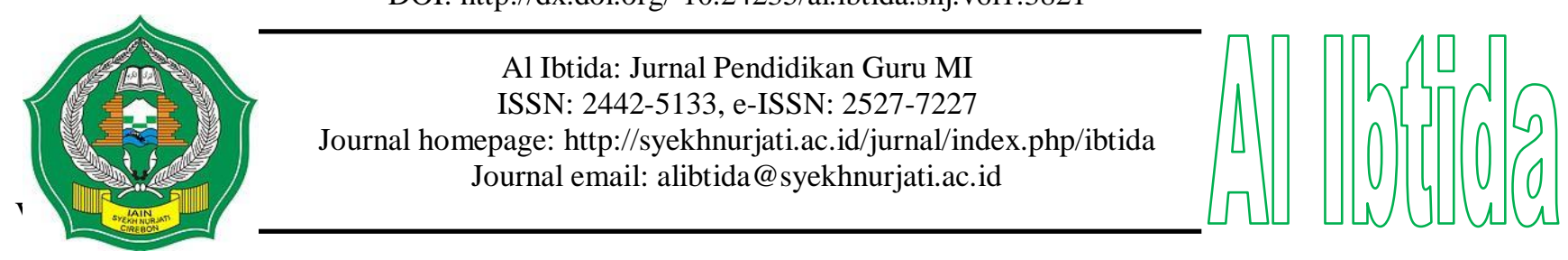

\title{
Learning Patterns of Deaf Students in Islamic Religious Studies
}

\author{
Moh. Irsyad Fahmi MR* \\ *Master Program of Madrasah Ibtidaiyah Teacher Education, \\ Universitas Islam Negeri Sunan Kalijaga Yogyakarta \\ Email: fahmienchanter@gmail.com
}

\author{
Khabibur Rohman** \\ ** Department of Islamic Education Management, Faculty of Tarbiyah and Teacher Training, \\ IAIN Tulungagung \\ Email: haabibur.rohman@gmail.com
}

Received: January $16^{\text {th }}, 2019$. Accepted: June $14^{\text {th }}, 2019$. Published: June $30^{\text {th }}, 2019$.

\begin{abstract}
This research is intended to learning patterns of deaf students in Islamic Religious Studies (IRS) class at the elementary school level, determine the preparation of students, and identify the factors that support and hinder the learning process. The methods used in this research is qualitative, with a case study approach. Data was collected using the interview and documentation approaches. Data analysis involved content analysis. The study finds that deaf students follow traditional learning patterns, in which teachers are equipped with materials, tools, and media that can be used to convey abstract ideas. In such a learning pattern, teachers play the most important role in determining content and methods to enable students to follow the lessons. Factors supporting the learning process include parent concern and teacher cooperation. A major factor hindering the learning process, meanwhile, is students' limited linguistic abilities, as a result of which they have difficulty understanding the lessons.
\end{abstract}

Keywords: deaf, learning patterns, special education.

\begin{abstract}
Abstrak
Penelitian ini dimaksudkan untuk menguraikan pola pembelajaran siswa tunarungu di kelas Pendidikan Agama Islam (PAI) pada tingkat sekolah dasar, memahami persiapan siswa, dan mengidentifikasi faktor-faktor yang mendukung dan menghambat proses pembelajaran. Metode yang digunakan dalam penelitian ini adalah kualitatif, dengan pendekatan studi kasus. Data dikumpulkan melalui wawancara dan dokumentasi. Analisis data yang digunakan adalah analisis isi. Penelitian ini menemukan bahwa siswa tunarungu masih mengikuti pola pembelajaran tradisional, di mana guru dengan menggunakan bahan, alat, dan media menyampaikan ide-ide abstrak. Dalam pola pembelajaran tersebut guru memainkan peran paling penting dalam menentukan konten dan metode yang memungkinkan siswa untuk mengikuti pelajaran. Faktor pendukung proses pembelajaran meliputi perhatian orang tua dan kerjasama guru. Faktor utama yang menghambat proses
\end{abstract}


belajar adalah kemampuan linguistik siswa yang terbatas, sehingga mereka mengalami kesulitan dalam memahami pelajaran.

Kata kunci: tunarungu, pola pembelajaran, pendidikan khusus.

\section{INTRODUCTION}

Human are born with different potentials. Education is a tool for developing the innate potential of each child. For this reason, educational institution should design learning activities that place each student as a unique and whole person (Rohman, 2016). The school system should provide support so that every child with various backgrounds and differences in potential can still develop their potential.

As an effort to optimize the potential of children from various backgrounds, including children with special needs, inclusion-based schools were established. Without any exception, school should facilitate children who have special needed in physical, mental, intellectual, and emotional disorders (Utina, 2014). The school system was designed to students for gets the same opportunity in developing himself. For this reason, schools need to understand the characteristics of each child.

So far, we have simplified the definition of services and support for children with special needs by providing adequate facilities and infrastructure. In fact, social and emotional support is also needed. For example, in addition to providing comfortable classrooms, the support is needed in advocacy services for deaf children and others (MacAllister \& Riddell, 2019). According to Winarsih (2017), deaf children feel hard in hearing or unable to hear, generally as a result of one or more parts of the auditory system. Students' inability to hear as their peers influences their lives in complex ways, most prominently in their communications.

Deaf children are often isolated from their social environment, be it at home, at school, at work, or in the community (Fusick, 2008). Article 5 of Law No. 20 of 2003 regarding the National Education System stipulates that every citizen of Indonesia has the same right to a quality education. Deaf children, despite their disability, have the right to receive an appropriate education. In the school system, deaf children may choose to study at special schools. These schools, known as extraordinary schools (sekolah luar biasa-B/SLB), provide education to disability children and give them the opportunity to study and learn together with their peers. They will follow a program that has been adapted to suit their needs and abilities.

Deaf children live within a segregated world, and study within extraordinary schools where most students share the same diagnosis. Successful learning of deaf children depends on their ability to emotionally and socially adapt to the various learning patterns in school. Unprepared children in learning will experience obstacles in the process. Students' readiness for 
learning must be considered to ensure optimal learning. According to Slameto (2010), readiness can be understood as the action to respond or react. This readiness comes from within the student, and the student's reflective maturity. It indicates a student's readiness to improve his/her proficiency (Slameto, 2010).

Essentialy, Learning is a process in which teachers and students interact, either directly (face to face) or indirectly (through learning media). Learning processes can be distinguished based on the different forms these interactions take. There are different forms of learning processes and patterns.

Regardless of the role of family and environment, the progress and achievements of children are strongly influenced by the learning patterns applied in school. For this reason, the school needs to make a system that is conducive to optimizing its role. The following are some of the things that are very important about the quality of student learning, including learning methods, teacher competencies and facilities (infrastructure) in the school (Kurniasari, 2015).

According to Morris as cited in Rusman (2013), there are four categories of learning patterns, as shown in the following picture:

\section{1) Traditional learning pattern 1}

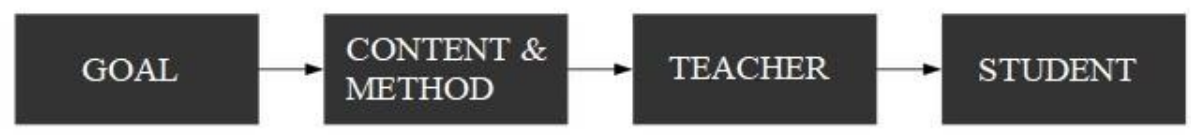

2) Traditional learning pattern 2

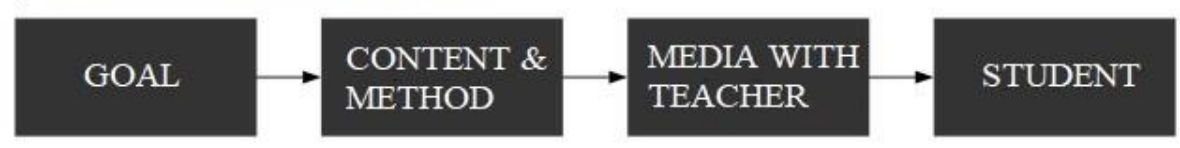

3) Teacher and media learning pattern

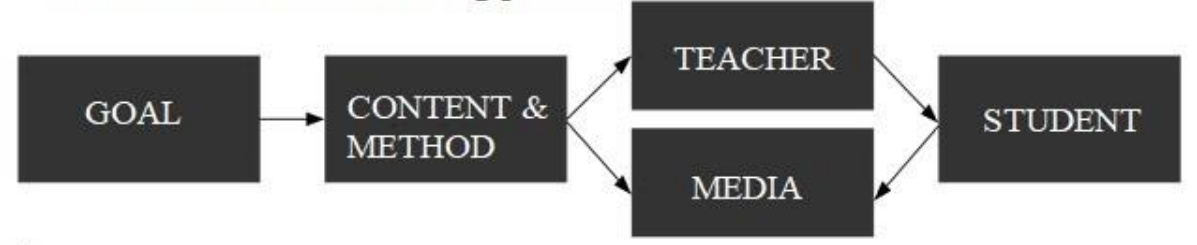

4) Mediated learning pattern

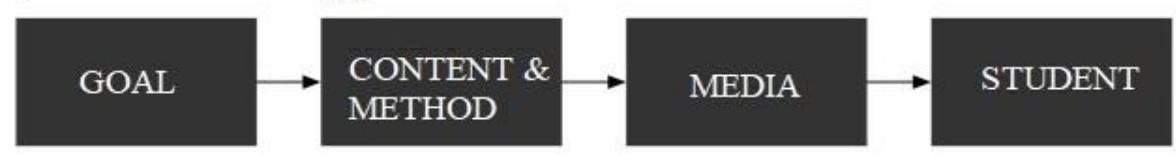

Picture 1: Learning pattern

The first is traditional learning pattern 1. This learning pattern involves teachers interacting directly with students, without any special tools/media. This learning pattern depends on the teacher's ability to remember the materials and to convey these materials orally to students. In this traditional learning pattern, the educator (teacher) has a central role in determining the contents and methods used for learning, as well as in determining the scores of 
the students. The teacher serves as the students' sole source in learning. In this model the teacher dominates the learning process. Such a learning pattern does not provide the opportunity for technology use in the learning process. Books, blackboards, and other teaching materials, and books have no role in the learning process. There is no space to provide the development of technology in education. This traditional learning pattern used to teach foreign languages, especially for writing skills. Listening and speaking skills are only rarely exercised (Wijoyo, 2018).

Second, traditional learning pattern 2. It involves the teacher interacting with students while using media and other equipment. In this pattern, the teacher is supported by various learning materials, known as learning props, which are used to explain abstract concepts. The development of science and knowledge has been influenced by this teaching pattern, and as such there is a tendency to formally include it as a standard element of the education system.

Meanwhile, the development of technology, particularly media and learning props, has continued (Sadler, Sonnert, Coyle, Cook-Smith, \& Miller, 2013). This tendency for standardization has occurred because of economic reasons, but it has the additional benefit of consolidating control over the learning process. This standardization affects, for example, the provision of school books, design of school buildings, shape of writing implements (boards etc.), instructional media, libraries, and laboratories. As a result of such input in the learning process, a new component is introduced: the equipment and props used by teachers to support the learning process and increase students' comprehension. These props and equipment are known collectively as learning media. This media provides another source of learning (in addition to the teacher) in this model. In this learning pattern, the teacher continues to play a determinant role in the learning process in class, but is not in complete control owing to the involvement of the media as a supplementary source of learning. In the teaching of foreign languages, teachers are expected to utilize available learning media, be it pre-prepared media or media prepared by the teachers themselves.

Third, teacher and media learning pattern. It involves the teacher and media together with the students, and considers the limitations of the teacher. It holds that a teacher cannot serve as the sole source of learning, and as such in this learning process the teacher will use various forms of media as sources of learning in lessons. Students will receive information not only from the teacher, but also from various media such as magazines, modules, radio broadcasts, educational television programming, computer programming, and the internet. In this learning pattern, teacher and media take turns for interacting with the student. The Development of science and technology has given humanity expanded horizons of knowledge. The current generation must learn more than the previous generation. Likewise, future generations will require education to 
ensure them in adapting technological developments. In the past few decades, the teaching pattern of teachers has undergone many developments. They no longer teach by conventional means. Their position when in class is also no longer dominant. The most prominent are the use and use of media in their learning activities (Endedijk, 2014).

As an implication of the developments in science and technology, as well as in human society over time, education and teaching systems must be efficient and effective. All types of knowledge and messages, both verbal and non-verbal, must be transformed into the new systems. In this learning pattern, the media is positioned not only as a product of human knowledge, but also as a means of communicating knowledge and messages. Furthermore, the media can be used to develop special skills using the most recent techniques.

Standardized input has also emerged in this learning pattern, in which the teacher is helped by the media, as it has (over time) not produced optimal results. There has been a tendency for learning to come from other sources (aside from teachers) that are prepared by a group of media experts. As a result, the system has become one in which the teacher individually plays a role, on the one hand, and the teacher/media play a role, on the other hand; both interact with students. In this, the teacher functions are to control students and ensure discipline and their interest. Meanwhile, the media, as a source of learning, serves to control the presentation of material. In foreign languages teaching, teacher will be involved and present in class. However, the media will also be developed together with students. Furthermore, the teaching of foreign language skills requires the students to have a receptive and productive command of oral and written language.

Fourth, mediated learning pattern. The mediated learning pattern, or long-distance learning, uses any type of media or learning materials. It applies the media as students' main source of learning. This learning pattern has emerged in response to increase quantitative and qualitative demand for education. There has emerged a demand for high quality and professional teachers. The limited availability of such teachers has also driven the development of this model. Because the number of professional teachers cannot be increased rapidly, efforts have been made to find and develop learning media.

What is the educator's role? Professional educators are tasked with systematically and programmatically producing modules and learning packages. In fact students tend to learn independently in their interactions with the learning media prepared by media experts and teachers. In the teaching of foreign languages, this pattern does not require materials and may even eliminate the role of the teacher. The education process occurs through the learning media, with modules and programs being followed for independent learning. The main limitation of this 
pattern is the media cannot educate students, even though the teacher is often replaced by the media he/she creates.

These learning patterns suggest that, as learning media-including software and hardware-has developed rapidly and transformed the position of the teacher in the learning process. The teacher is no longer the sole source of learning; learning may occur through magazines, modules, radio broadcasts, educational television programming, computer media (CBI or computer-based instruction, including drills, simulations, and instructional games), and the internet. In the present (and the future), the teacher serves not as the director of learning, but rather as a facilitator of students' learning through the optimal use of media as a source of learning. In fact, it is possible that, in the future, the media will take a central role in the learning process (mediated learning process), such as through computer-based instruction.

Others have argued that teachers' interactions with students in the learning process are extremely diverse, ranging from teacher dominance through student-led learning. These interactions may be classical, group-based, or individual. Meanwhile, activities may include listening to information, reading materials, discussion materials, participating in training, or watching demonstrations. In varying the learning methods used and preparing learning materials, teachers must consider the main principles of suitability, accuracy, fluency, and continuity (Rusman, 2013).

Readiness to learn is an important issue in extraordinary elementary schools. Children show their readiness to positively respond to education and learning methods and media, as well as the facilities available for deaf children. This must also receive the support of teachers and parents. A common problem affecting student readiness is students' limited ability to communicate linguistically. Teachers must face their students directly when they are speaking, and must also speak clearly. This, of course, affects deaf students' readiness to learn.

Readiness refers to the condition in which someone is prepared to respond to something in a certain way. Learning readiness, thus, refers to a situation in which someone is prepared for learning activities (Djamarah, 2011). There are three aspects that affect readiness: (a) physical, mental, and emotional condition; (b) needs and motives; (c) learned skills and knowledge. Meanwhile, factors that influence learning readiness include: (a) family factors; (b) school factors (teacher, class, and resources); (c) and environmental factors (Slameto, 2010).

Microsystem structures provide significant input in the direct interactions among social actors (Berns, 2004). Children interact directly with their surroundings and their communities, in which parents respond to teachers through their attitudes, friendships, administration, programs, evaluations, and involvement. An important factor in deaf students' readiness is their actual interactions in class. By involving students, and with positive support, good achievements can be 
realized. Students can be considered ready for learning when they respond positively within the classroom. The best way of achieving understanding and cooperation is by involving them and providing positive support (Smith, 2010).

Research on learning for the deaf have been done on some subjects. Most of them use a variety of creative and innovative media. As research conducted by Malatista \& Sediyono (2010) entitled Model Pembelajaran Matematika untuk Siswa Kelas IV SDLB Penyandang Tunarungu dan Wicara dengan Metode Komtal Berbantuan Komputer. In this study, the computer becomes the most effective media in improving the quality of mathematics learning for the deaf. The importance of information technology in line with research conducted by Marzal (2014) in English language learning for the deaf. Learning runs better with computer facilities and Edmodo software. In addition, research on the importance of using technology in learning have also been carried out by Yuniati (2011) that focus on software development for increasing deaf students ability in speech. In his research, the authors offer Multimedia Software for Sign Language Learning to introduce Letters and Numbers.

Deaf person have difficulties in mastering the language. Their limited linguistic abilitiy is caused by their problem in LAD (Language Acquisition Device). It was reviewed in a study conducted by Sugiarti (2015) focusing on the improvement of deaf vocabulary through the Images variation on Class V / B SLB Negeri Surakarta. This study reveals the importance of image media in teaching Indonesian to students. Difficulties in language learning also dissected in research by Linawati (2012), entitled Penerapan Metode Mathernal Reflektif Dalam Pembelajaran Berbahasa Pada Anak Tunarungu Di Kelas Persiapan SLB Negeri Semarang. This study founded alternative methods of learning for deaf students, by using reflective mathernal method. The method is more focused on the child's ability to conduct exploration on what they hear. Not by a formal language learning.

Related to the alternative solutions in language learning barrier for the deaf have been reviewed by Filina (2013) through his research which focus on the development of role playing method for increasing deaf student vocabulary. The conclusion from these studies is that the method can improve the quality vocabulary learning in deaf students. In addition to problems with hearing impairment, language limitations that occurred are the result of their weakness in reading. As outlined by Aulia (2012) that read with the understanding becomes important for deaf students. So that the information they obtain is not only derived from what they hear.

The significance of the study is affirming the importance of creative and innovative media in the learning process for students with hearing impairment. From the previous studies researcher found the limitation of the implementation of religious studies for deaf student 
learning. Even, religious studies are important for deaf students as well as other subject. There is no research that offers learning concepts and patterns of IRS on deaf students.

Researcher also found that there is no practice of learning in deaf students who use the traditional approach with four patterns. On the other hand, the research has been done could not decipher the solution of problems faced limited linguistic abilities deaf students. These research gap will be analyzed through this research which focus on the implementation of IRS to deaf students and the solution for increasing their linguistic abilities It is interesting to examine the learning patterns of deaf students studying at Indonesia's extraordinary elementary schools, as well as the factors that support and hinder them in the learning process. This research seeks to examine the learning patterns of deaf students at an extraordinary elementary school and their learning readiness, as well as the factors that support and hinder them in their learning.

\section{METHODS}

This research is a qualitative with the case study approach. The qualitative method is a research procedure that produces descriptive-qualitative data, i.e. the written or spoken words of the people being researched or their behaviors (Moleong, 2010). The case study approach involves the detailed examination of an 'object' that is perceived as a 'case' represents the 'whole', using various sources of data (Hancock \& Algozzine, 2006).

Through this qualitative and case study approach, the reality of deaf students' learning patterns can be understood as the result of dynamic and significant mental activities (Sugiyono, 2015). Purposive sampling was used (Poerwandari, 2009). This data sampling technique involves the selection of subjects based on the research problem and goal. For this article, the research subjects were four deaf students (categorized as having profound hearing loss) studying in the sixth grade of extraordinary elementary school.

Data collection was completed using the interview and document analysis techniques. The data analysis techniques content analysis. This research uses semi-structured interviews, which are categorized as in-depth interviews. In practice, these interviews are more flexible than structured interviews.

Based on the conditions in the field, including the hearing loss of the students, direct interviews could be used to collect data. Written interviews were conducted. The researcher interviewed significant persons in the students' lives, including their parents and teachers. This research also involved non-participatory observation of the research subjects in the classroom, through which data was collected and verified. The document analysis method focused on the students' report cards after one semester of studies. 
The truth of the data collected can be better ascertained if the truth is stated by more than one subject. For data verification, the researcher used source triangulation and method triangulation techniques (Moelong, 2010). Source triangulation refers to the comparison and verification of information through different sources. Method triangulation refers to the verification of research findings through diverse methods, including in this article interviews and document analysis

\section{RESULTS AND DISCUSSION}

The four children as the objects of this study have been naturally deaf since childhood. They are categorized as having profound hearing loss (Haenudin, 2013). The first child experienced a loss of hearing of $110 \mathrm{~dB}$; the second a loss of $96 \mathrm{~dB}$; the third a loss of $120 \mathrm{~dB}$; and the fourth a loss of $98 \mathrm{~dB}$. The school studied utilizes teachers and teaching tools with students, and thus can be categorized as the Traditional Learning Pattern 2. In this learning pattern, teachers are supported by various learning materials and props, which help them to explain and perform the abstract materials.

In teaching Islamic religious lessons, content was almost the same as those used in regular schools, focusing on the Holy Quran, aqidah (belief), akhlaq (virtue, morality and manners), and fiqih (jurisprudence). However, it is simplified in its teaching in accordance with the abilities and the needs of students. For evaluation, the YPLB Extraordinary Elementary School-B in Blitar uses some terms of examinations, quizzes, and national examinations. For the IRS class, tests are both written and practical. However, for examinations, the questions used are provided by the local government and it is same the regular elementary schools.

The development of science has influenced teaching methods, and thus there has been a tendency to standardize the input in education systems. Meanwhile, technology, including media and facilities, has also developed. The tendency for standardization has occurred because of the economic reasons, but it has the additional benefit of consolidating control over the learning process. This standardization affects, for example, the provision of school books, design of school buildings, shape of writing implements (boards etc.), instructional media, libraries, and laboratories.

As a result of such input in the learning process, a new component is introduced: the equipment and props used by teachers to support the learning process and increase students' comprehension. These props and equipment are known collectively as learning media. This media provides another source of learning (in addition to the teacher) in this model. In this learning pattern, the teacher continues to play a determinant role in the learning process in class, but is not in complete control owing to the involvement of the media as a supplementary source 
of learning.

The learning media used by the IRS teacher at the YPLB Extraordinary Elementary School-B in Blitar are similar to those used in regular schools, including blackboards, pictures, and prayer rooms (mushola). The evaluation process is not only involves written tests, but also observation of students' everyday behavior as well as their worship practices in everyday life. Evaluation is conducted by considering cognitive, affective, and psychometrics aspects. In the evaluation, the standard used is somewhat different than the standard used for students who have not suffered hearing loss.

Based on the observations, deaf students' worship activities are strongly influenced by their own situations and their environments. For example, the school has a habit of holding communal prayers, and prayers at home must be controlled by parents, Parents should ask students to participate in c prayers together with them. During prayer, deaf students should be placed as close as possible to the imam, to ensure that the voice of takbir is heard. Similarly, as the school has taught students etiquette and character, parents should continue this education by ensuring that Islamic values are practiced in their daily lives. Parents should try to provide good examples or ask children to observe others.

The four students are currently finishing their sixth-grade studies at the YPLB Extraordinary Elementary School-B in Blitar. Owing to their deafness, they have frequently experienced difficult learning. This difficulty can be attributed to their limited linguistic abilities. This is supported by Effendi (2008), who writes that the hearing difficulties experienced by deaf children limits their vocabularies and hinders their language use and communications. According to the research conducted by Solikhatun (2013), the social interactions of deaf students in their communities indicate a lack of confidence; they feel difficult to close to others, particularly children who are not deaf. However, the majority of students do not experience shame or a lack of confidence; in fact, they sometimes see themselves as superior to others, particularly students with intellectual disabilities, and thus limit their friendships with such children.

The four students exhibit motivation and dedication in their learning. This is apparent, for example, in their consistent completion of the tasks given by their teachers and their attention to their teachers' explanations. They are also disciplined, always bringing the materials needed for their lessons. Furthermore, they also respect their teacher. Their motivation to learn pushes them to prepare themselves for learning and to study actively, creatively, effectively, innovatively, and happily (Effendi, 2008).

The four students expressed a desire to study at the extraordinary school, so they could learn like students who are not deaf; as these students are part of broader society, they cannot be separated from the social values in effect. The first student began attending the extraordinary 
school with confidence, as the student had received support and motivation from the student's parents. The second and third students entered the school because their parents wanted them to socialize with others. The second and third students agreed to do as their parents' desired. The fourth student was initially uncertain about studying at the extraordinary school, but with the support of the parents the student found the confidence to attend to the school.

The four students have no cognitive disabilities. Nonetheless, their individual limitations have led to them receiving different scores; all of the scores are below the standards for the subject. In IRS, the first student received a 2.75 out of a possible 4.0; the second student received a score of 2.68 out of 4.0 ; the third 2.84 out of 4.0 ; and the fourth 2.65 out of 4.0 . Pintner, a psychologist who has worked among the deaf, argues that deaf children exhibit motoric and mechanic skills as well as concrete intelligence, but have difficulty in academia and with language (Effendi, 2008).

The four students have families that have supported them greatly. The parental support received by them has tended to take the same forms: love, care, guidance, and encouragement. Student's parents have also supported them through their activities and their money, and have worked to provide them with everything they need in their studies. The support received by the four has given them positive perceptions of their families, and thus improved their readiness. Slameto (2010) states that the attention of parents strongly influences students' readiness to learn. This is supported by ecology theory, as expressed by Bronfrenbenner in Berns (2004), who notes that families are microsystems. They provide care, love, and various opportunities that can improve children's readiness.

Schools also have an important role in determining deaf students' readiness to learn. Where schools are able to provide good communications, use active/interactive learning models, utilize learning props efficiently, and create order and discipline, children have improved readiness and can better follow their lessons (Slameto, 2010). According to Bronfrenbrenner in Berns (2004), schools are microsystems in which children formally learn about their surroundings and interact significantly with their community. Teachers support the development of skills and behaviors by acting as role models and by motivating children to be ready to learn. Their school, as the place where the four subjects learn, provides the subjects with a positive contribution, including through the various extracurricular activities that teach them skills. This is supported by teachers who work together to guide them in the classroom. School have to provide packets that enable them to review the materials taught in class.

The four students have positive interactions. Their friends show significant concern for them and work together with them to help the subjects develop at home. Interactions between subjects in class and elsewhere are likewise positive. Having such friends has a positive effect on 
children's studies, while having friends who are negative influences will negatively affect children's studies (Slameto, 2010). According to Bronfrenbenner in Berns (2004), friends are also part of the microsystem, the setting in which children interact with each other without adult supervision. By having friends, the subjects can better understand who they are and what they can do, as well as their capabilities relative to others. Friends will provide support to each other, and they may share their experiences and play together. As such, positive interactions with others will positively affect children's readiness to learn.

Based on the above discussion, it can be seen that the four students exhibit a readiness to learn. The conditions that support their readiness are the guidance, love, and cooperative parents. Parents also support children through their labor, their money, and their input so that their children's learning needs can be fulfilled. Friends also help the subjects improve their readiness to learn in class. However, a significant obstacle is faced by the third subject, who has significant difficulty communicating and thus cannot as easily follow the lessons as the other subjects.

The family, as the smallest social unit, is expected to provide social support as well as concern, love, and assistance. The school, meanwhile, is hoped to improve teachers' ability to teach deaf children in class. Because deaf children require special treatment and different teaching methods than other children, the school must provide special training to IRS teachers to facilitate the learning process. The government is also hoped to fulfill the needs of deaf children and provide an accurate assessment of their abilities that recognizes their physical limitations. By recognizing their modality, a teacher can more readily identify the children's needs in their studies.

\section{CONCLUSION}

The learning pattern used by the subjects is the Traditional Learning Pattern 2. The four students are ready to learn, as expected of them. They are supported by their parents, their school, and their friends, who support them through their labor, money, input, and guidance to ensure the students what they need. The subjects also receive the love, care, and encouragement of those closest to them and their parents. As such, the students have shown a positive response to the school as their learning environment. The school, teachers, and government are hoped to provide support to children with special needs, including deaf children, by improving facilities and teacher readiness to ensure that these children can follow lessons. In order to determine the right teaching pattern for deaf children, teachers need to first make observations about the child's hearing level. In addition, the teacher must also show an attitude of compassion and love, because love and compassion are languages that can be universally understood. 


\section{REFERENCES}

Aulia, R. (2012). Meningkatkan Kemampuan Membaca Pemahaman pada Anak Tunarungu. Jurnal E-Jupekhu, 1(2), 347-357.

Bern, R. M. (2004). Child, family, community. 6th ed. United States: Wadswoth.

Djamarah, S. B. (2011). Psikologi belajar [The psychology of learning]. Jakarta: Rineka Cipta.

Effendi, M. (2008). Pengantar psikopedagogik anak berkelainan [An introduction to the psychopedagogy of children with specialneeds]. 2nd ed. Jakarta: Bumi Aksara.

Endedijk, M. D. (2014). Student Teachers' Learning Patterns in School-based Teacher Education Programmes: The Influence of Person, Context and Time. Routledge.

Filina, Z. (2013). Efektifitas Metode Role Playing untuk Meningkatkan Kosakata Anak Tunarungu. Jurnal E-Jupekhu. 1(1), 311-318.

Fusick, L. (2008). Serving clients with hearing loss: best practices in mental health counseling. Journal of Counseling and Development, 86(1), 102

Haenudin. (2013). Pendidikan anak berkebutuhan khusus tunarungu [Educating children with special needs/deafness]. Jakarta: Luxima.

Hancock, D.R. \& Algozzine, B. (2006). Doing case study research: a practical guide for beginning researchers. New York and London: Teacher College Columbia University.

Kurniasari, N., D. (2015). Pola Pembelajaran dan Pengasuhan Pendidikan Anak Usia Dini di PAUD Madura. Jurnal Komunikasi. 9(2), 113-118

Linawati, R. (2012). Penerapan Metode Mathernal Reflektif Dalam Pembelajaran Berbahasa Pada Anak Tunarungu Di Kelas Persiapan SLB Negeri Semarang. Journal of Early Childhood Education Papers, 1: 1-7.

MacAllister, J. \& Riddell, S. (2019). Realising the educational rights of children with special and additional support needs: paradigm change or more of the same? International Journal of Inclusive Education. 23(5), 2

Malatista, R., \& Sediyono, E. (2010). Model Pembelajaran Matematika untuk Siswa Kelas IV SDLB Penyandang Tunarungu dan Wicara dengan Metode Komtal Berbantuan Komputer. JURNAL INFORMATIKA, 7(1), 7-26.

Marzal, J. (2014).Desain Media Pembelajaran Bahasa Inggris Untuk Siswa Tunarungu Berbantu an Teknologi Informasi Dan Komunikasi. Jurnal Tekno-Pedagogi, 4(2), 32-44.

Moleong, L.J. (2010). Metodologi penelitian kualitatif [Qualitative research methods]. Bandung: Remaja Rosdakarya.

Poerwandari, K. (2009). Pendekatan kualitatif [The qualitative approach]. 3rd ed. Depok: LPSP3, Universitas Indonesia.

Rohman, K. (2016). Optimalisasi Pendidikan Humanistik di Sekolah Dasar; Studi Multisitus di SD Insan Mulia Surabaya dan SDS Wahidiyah Tulungagung. Jurnal Dinamika Penelitian; Media Komunikasi Penelitian Sosial Keagamaan, 16(1)

Rusman. (2013). Model-Model Pembelajaran Mengembangkan Profesionalisme Guru. Jakarta: Rajawali Pers

Sadler, P. M., Sonnert, G., Coyle, H. P., Cook-Smith, N., \& Miller, J. L. (2013). The influence of teachers' knowledge on student learning in middle school physical science classrooms. American Educational Research Journal, 50(5), 1020-1049.

Slameto. (2010). Belajar dan factor-faktor yang mempengaruhi [Learning and the factors that influence it]. Jakarta: Rineka Cipta. 
Smith, D. J. (2010). Inklusi sekolah ramah untuk semua [Inclusive schools: friendly to all]. Bandung: Nuansa.

Solikhatun, Y. U. (2013). Penyesuaian Sosial Pada Penyandang Tunarungu di SLB Negeri Semarang. Educational Psychology Journal, 2(1).

Sugiarti, S. (2015). Upaya Meningkatkan Kosa Kata Anak TunarunguMelalui Media Variasi Gambar pada Siswa Kelas V/B di SLB Negeri Surakarta. Prosiding Seminar Nasional Pendidikan, 254-250.

Sugiyono. (2015). Metode penelitian kuantitatif, kualitatif, dan R\&D [Quantitative, qualitative, and R\&D research methods]. Bandung: Alfabeta.

Utina, S.S. (2014). Pendidikan Anak Berkebutuhan Khusus. Jurnal Manajemen Pendidikan Islam, 2(1), 72-78.

Wijoyo, A. (2018). Pengaruh Hasil Belajar Siswa dengan Menggunakan Multimedia Pembelajaran Interaktif untuk Sekolah Menengah Pertama dan Sekolah Menengah Atas. Jurnal Informatika. 3(1), 45-55

Winarsih, M. (2017). Intervensi dini bagi anak tunarungu dalam pemerolehan bahasa [Early intervention for deaf students in language learning]. Jakarta: Department of National Education.

Yuniati, Y. (2011). Pengembangan Perangkat Lunak Pembelajaran Bahasa Isyarat bagi Penderita Tunarungu Wicara. Jurnal Genric, 6(1), 29-32. 